\title{
ANALISIS KEMAMPUAN MULTIREPRESENTASI SISWA PADA MATERI KESETIMBANGAN KIMIA DI MASA PANDEMI COVID-19
}

\author{
Sita Fatimah Zahro, ${ }^{1}$ *, Ismono ${ }^{2}$ \\ ${ }^{12}$ Program Studi Pendidikan Kimia, Universitas Negeri Surabaya. Jalan Lidah Wetan, Kec. \\ Lakarsantri, Surabaya, Jawa Timur 60213, Indonesia. \\ * Coressponding Author. E-mail: sita.17030194052@mhs.unesa.ac.id
}

Received: 30 Desember 2020

Accepted: 23 Mei 2021

Published: 28 Mei 2021

doi: 10.29303/cep.v4i1.2338

Penelitian ini bertujuan untuk mengetahui kemampuan multirepresentasi yang terdiri dari representasi makroskopik, representasi submikroskopik, dan representasi simbolik siswa kelas XI IPA SMA Negeri 1 Krian tahun ajaran 2020/2021 pada materi kesetimbangan kimia di masa pandemi covid19. Jenis penelitian ini merupakan penelitian deskriptif. Metode yang digunakan dalam penelitian yaitu mix methode dengan tipe embedded. Subjek penelitian ini adalah siswa kelas XI IPA yang berjumlah 31 siswa. Teknik pengumpulan data berupa pengukuran hasil tes tulis dan hasil wawancara bebas terpimpin. Instrumen penelitian berupa 15 soal tes uraian yang memiliki validitas 0.5 hingga 0.8 , reliabilitas 0.934 , daya pembeda 0.5 hingga 08 , dan tingkat kesukaran 0.4 hingga 0.8 . Berdasarkan hasil penelitian menunjukkan bahwa kemampuan multirepresentasi siswa pada materi kesetimbangan kimia di masa pandemi covid-19 yang dilakukan secara daring tergolong rendah dengan persentase rata-rata kemampuan representasi makroskopik, representasi submikroskopik, dan representasi simbolik siswa secara berturut-turut sebesar $35.01 \%$ dengan kategori kurang, $40.59 \%$ dengan kategori kurang, dan $50.55 \%$ dengan kategori cukup.

Kata Kunci: multirepresentasi, makroskopik, submikroskopik, simbolik, kesetimbangan kimia

\section{Analysis Of Students' Multirepresentation Skills On Chemical Equilibrium During The Covid-19 Pandemic}

\begin{abstract}
This study aims to determine the ability of multi-representation consisting of macroscopic representations, submicroscopic representations, and symbolic representations of XI IPA SMA Negeri 1 Krian academic year 2020/2021 on chemical equilibrium material during the Covid-19 pandemic. This type of research is a descriptive study. The method used in this research is the mix method with the type embedded. The subjects of this study were 31 students of XI IPA. Data collection techniques are measuring the results of written tests and the results of guided free interviews. The research instrument was 15 essay test questions with a validity of 0.5 to 0.8 , reliability of 0.934 , distinguishing power of 0.5 to 08, and difficulty level of 0.4 to 0.8. The research results show that the ability of students' multirepresentation on chemical equilibrium material during the Covid-19 pandemic, which done online was low. The average percentage of macroscopic representation, submicroscopic representation, and symbolic representation of students is $35.01 \%$ with a low category, $40.59 \%$ in the less category, and $50.55 \%$ in enough category.
\end{abstract}

Keywords: multi representation, macroscopic, submicroscopic, symbolic, chemical equilibrium

\section{PENDAHULUAN}

Kimia adalah subjek yang berdasarkan pada konsep abstrak sehingga sulit dipahami, terutama ketika siswa diminta untuk memahami sesuatu tanpa melihat secara langsung (Stojanovska, M. Petruševski, dan Šoptrajanov 2017). Fenomena yang ada pada pembelajaran kimia ini menunjukkan bahwa mata pelajaran kimia adalah pelajaran yang sulit bagi 
kebanyakan siswa. Selain itu, penyebab tinginya kesulitan siswa untuk memahami ilmu kimia juga dipengaruhi oleh karakteristik ilmu kimia yang berurutan serta berhubungan dengan perhitungan.

Pelajaran kimia sulit dipahami ini didukung dengan pendapat $77 \%$ dari 30 siswa berdasarkan kuisioner pra penelitian yang telah dilakukan. Berbagai model digunakan untuk mendeskripsikan, menjelaskan, dan membuat prediksi tentang sifat dan proses zat kimia (Talanquer, 2011). Menurut Adadan (2013), apabila siswa mampu merepresentasikan ke dalam tiga level representasi, ilmu kimia akan lebih mudah dipahami. Kemampuan untuk memecahkan masalah pada pembelajaran kimia menggunakan tiga level representasi kimia dapat menunjukkan keberhasilan siswa dalam proses belajar kimia (Farida et al. 2017), sehingga berdasarkan uraian tersebut, kemampuan representasi perlu dikembangkan dalam pembelajaran kimia.

Tiga level representasi kimia terdiri dari representasi makroskopik, representasi submikroskopik, dan representasi simbolik yang saling menunjang dan berkaitan dalam pembelajaran kimia. Pada tingkat makroskopik, siswa dihadapkan pada suatu peristiwa yang dapat diamati di alam sekitar ataupun melalui laboratorium (Farida et al. 2018).

Representasi submikroskopik dapat dipahami dengan dukungan representasi makroskopik. Representasi submikroskopik ini berkaitan dengan partikel yang tidak kasat mata dalam bentuk atom, molekul dan partikel sub atom. Representasi submikroskopik menjadi pendukung untuk memperjelas peristiwa makroskopik yang terjadi (Irwansyah, Ramdani, dan Farida 2017). Representasi makroskopik dan submikroskopik digambarkan dengan simbolsimbol dan juga persamaan yang melibatkan perhitungan secara kuantitatif (Davidowitz, Chittleborough, dan Murray 2010).

Treagust (2018) menyatakan bahwa tingkat makro kimiawi seperti pembakaran gas metana mencakup apa yang dapat dilihat, dicium, atau didengar seseorang saat melakukan percobaan. Proses pembakaran metana dapat dipahami dengan mengetahui apa yang terjadi di tingkat submikro, yaitu metana yang bercampur dengan oksigen menghasilkan karbon dioksida dan air. Untuk memiliki pemahaman yang lebih dalam, seseorang perlu mengetahui bahwa molekul metana terbuat dari karbon dan hidrogen dan ini dapat direpresentasikan pada tingkat simbolik dalam persamaan kimia: $\mathrm{CH}_{4}+2 \mathrm{O}_{2} \rightarrow$
$\mathrm{CO}_{2}+2 \mathrm{H}_{2} \mathrm{O}$. Pada tingkat simbolik, persamaan kimia ini dapat digunakan untuk mewakili perubahan zat di tingkat makro atau interaksi partikel di tingkat submikro. Dalam prakteknya di kelas, representasi makroskopis, submikroskopis, dan simbolik telah digunakan tetapi tidak mempertimbangkan keterkaitan antara ketiganya (Chuenmanee \& Thathong, 2018)

Berbagai penelitian terdahulu menunjukkan bahwa tingkat kemampuan multirepresentasi kimia siswa tergolong rendah. Peelitian yang dilakukan oleh Wahyudi, Qurbaniah, dan Sartika (2018) mengenai multirepresentasi pada materi laju reaksi aspek simbolik, makroskopik, dan mikroskopik berturut-turut adalah 70,57\% (kategori baik), 76,52\% (kategori baik), dan 41,25\% (kategori cukup). Penelitian yang dilakukan pada 36 siswa kelas XII MIA salah satu SMA Negeri di Kota Serang menunjukkan bahwa sebanyak 21.92\% siswa sudah mampu mengkoneksikan ketiga level representasi kimia, $25.55 \%$ siswa cenderung hanya mampu menginterkoneksikan pada dua level representasi, $14.96 \%$ siswa cenderung lebih memahami konsep pada level representasi submikroskopik, dan sebanyak $37.56 \%$ siswa belum mampu mengkoneksikan konsep pada tiga level representasi (Safitri, Nursaadah, dan Wijayanti 2019).

Kegiatan belajar mengajar pada masa pandemi Covid-19 tidak dapat dilaksanakan secara tatap muka di sekolah seperti yang telah biasa dilakukan. Menurut Surat Edaran Menteri Pendidikan dan Kebudayaan Nomor 4 Tahun 2020 tentang Pelaksanaan Kebijakan Pendidikan Dalam Masa Darurat Penyebaran Covid-19, proses belajar dari rumah dilaksanakan dengan pembelajaran jarak jauh. Kapasitas daya ingat siswa akan meningkat apabila menghadiri sekolah (Jonsson, et al., 2017). Sehingga, kegiatan sekolah harus tetap dilaksanakan sebagaimana semestinya dengan menggunakan pembelajaran jarak jauh. Kemampuan multirepresentasi siswa yang melaksanakan pembelajaran jarak jauh (PJJ) bisa jadi berbeda dengan sebelumnya yang tidak dilaksanakan secara PJJ. Menurut Abidin (2020) pembelajaran jarak jauh merupakan proses pembelajaran yang tidak terjadi tatap muka secara langsung antara guru dan siswa, sehingga pembelajaran menekankan pada sistem pembelajaran mandiri dan menggunakan teknik-teknik khusus dalam mendesain materi pembelajaran melalui berbagai media seperti komputer, televisi, radio, telepon, internet, video dan lain sebagainya. 


\title{
Chemistry Education Practice, 4 (1), 2021 - 32
}

\author{
Zahro', Ismono
}

Pembelajaran daring merupakan salah satu jenis PJJ. Sistem pembelajaran daring adalah sistem pembelajaran yang dilakukan secara online dengan jaringan internet.

Proses belajar mengajar antara guru dan siswa dilaksanakan pada waktu yang sama tetapi tanpa adanya tatap muka secara langsung dengan berbagai aplikasi yang dapat mendukung, seperti whatsapp, telegram, zoom meeting, google meet, google classroom, quiepper school, ruang guru dan berbagai aplikasi lainnya (Munir, 2012). Berdasarkan angket yang telah disebarkan pada 30 siswa, seluruh siswa mengungkapkan bahwa pembelajaran masih dilakukan secara daring melalui video conference.

Perubahan sistem belajar yang semula dilakukan secara tatap muka menjadi PJJ yang terjadi secara tiba-tiba dan tanpa persiapan yang matang mengakibatkan ketidaksiapan guru dalam mengikuti perubahan pembelajaran berbasis teknologi dan informasi (Asmuni 2020).

Berdasarkan uraian-uraian tersebut, kemampuan multirepresentasi siswa di masa pandemi Covid-19 perlu dianalisis agar didapatkan informasi yang nantinya dapat mendiagnosis kesalahan siswa ataupun metode yang digunakan dalam kegiatan belajar megajar di masa pandemi Covid-19 sehingga dapat mengupayakan jalan keluar untuk memecahkan masalah.

Materi yang diangkat pada penelitian ini adalah kesetimbangan kimia, materi ini memiliki karakteristik tiga level representasi. Materi kesetimbangan kimia mencakup jenis-jenis kesetimbangan reaksi dan faktor-faktor yang mempengaruhinya. Pada kesetimbangan dinamis siswa harus bisa mengamati kesetimbangan yang terjadi dengan panca indra (makroskopis), selain itu siswa juga perlu dapat memahami secara mikroskopis yang terjadi pada kesetimbangan tersebut. Pemahaman mikroskopis juga diperlukan pada pokok bahasan faktor-faktor yang mempengaruhi pergeseran kesetimbangan kimia. Sedangkan kemampuan simbolik siswa dapat terlihat pada tetapan kesetimbangan kimia. Oleh sebab itu, pada materi kesetimbangan kimia siswa harus dapat memahami ketiga level representasi kimia agar dapat mencapai tujuan pembelajaran dengan baik.

Kebanyakan siswa merasa kesulitan pada materi kesetimbangan kimia. Hal ini dibuktikan dengan hasil penyebaran kuisioner yang diberikan pada 30 siswa, sebanyak $73 \%$ siswa menyatakan bahwa materi kesetimbangan kimia adalah materi yang sulit dipahami. Banyaknya siswa yang kesulitan dalam hitungan yang ada dalam materi kesetimbangan kimia sebanyak $77 \%$, banyaknya siswa yang kesulitan dalam mengaitkan materi kesetimbangan kimia dengan fenomena sehari-hari sebanyak $72 \%$, dan banyaknya siswa yang kesulitan dalam merepresentasikan senyawa-senyawa kimia atau proses kimia yang tidak kasat mata sebanyak 87 $\%$. Berdasarkan berbagai uraian tersebut, maka dilakukan penelitian dengan judul analisis kemampuan multirepresentasi siswa pada materi kesetimbangan kimia di masa pandemi Covid-19.

\section{METODE}

Jenis penelitian yang digunakan yaitu penelitian deskriptif dengan metode mix methode tipe embedded. Mix methode merupakan pendekatan penelitian yang menggabungkan penelitian kuantitatif dan penelitian kualitatif. Embedded design adalah desain penelitian dengan pengumpulan data kuantitatif dan kualitatif dengan salah satu tipe data sebagai data pendukung dalam desain keseluruhan (Creswell dan Creswell 2018). Penelitian ini menggunakan data kuantitatif sebagai data utama dan data kualitatif sebagai data pendukung. Penelitian dilakukan pada bulan November hingga Desember 2020. Penelitian ini menyelidiki kemampuan multirepresentasi materi kesetimbangan kimia pada siswa kelas XI IPA 7 SMA Negeri 1 Krian tahun ajaran 2020/2021 di masa pandemi Covid-19 dengan menyelesaikan soal-soal kesetimbangan kimia.

Pada penelitian ini menggunakan instrumen berupa tes tulis dan wawancara. Data kuantitatif didapat dari hasil tes tulis yang berisikan 15 soal uraian mencakup representasi makroskopik, submikroskopik, dan simbolik yang dikembangkan oleh peneliti. Insrumen tes yang telah disusun dilakukan uji validitas konten terlebih dahulu oleh dua validator ahli. Proses uji validitas konten oleh ahli ini mendapatkan masukan untuk memperbaiki tata kalimat pada butir soal no 2, 3, 4, 5, 13, 14 dan 15 agar lebih mudah dipahami oleh siswa, kemudian validator ahli juga memberikan kritik dan saran untuk mengubah soal pada nomor 1, 2, 3, dan 4 agar lebih sesuai dengan representasi yang diukur yaitu makroskopis dan soal nomor 10 agar lebih sesuai dengan representasi submikroskopik. Berdasarkan saran yang diberikan oleh kedua validator ahli, dilakukan perbaikan pada instrumen tes tersebut sehingga tes soal dapat 
dinyatakan valid dan layak digunakan dengan validitas 0,855 dengan kategori sangat tinggi.

Setelah instrumen dinyatakan valid oleh validator ahli, selanjutnya dilakukan uji coba instrumen untuk mengetahui nilai reliabilitas, validitas, daya pembeda, dan tingkat kesukaran butir soal pada 16 siswa kelas XII IPA. Nilai reliabilitas yang didapatkan berdasarkan hasil uji coba adalah 0,934 (sangat tinggi). Validitas tiap butir soal diuji dengan menggunakan koefisien product-moment berada pada kategori sedang hingga sangat tinggi. Daya pembeda soal berada pada rentang nilai 0,5-0,8 dengan kategori baik hingga sangat baik. Tingkat kesukaran soal memiliki nilai $0,4-0,8$ yang berada pada rentang mudah hingga sedang. Berdasarkan hasil uji ini, perangkat tes telah layak dan dapat digunakan.

Data kualitatif diperoleh melalui hasil wawancara siswa. Wawancara yang digunakan merupakan wawancara bebas terpimpin. Wawancara ini dilakukan dengan mengacu pada pedoman yang berisikan garis besar dari pertanyaan wawancara.

\section{Teknik Pengumpulan Data}

Beberapa tahapan yang dilakukan untuk mendapatkan data terdiri dari dua tahap, yaitu tahap persiapan dan tahap pelaksanaan. Tahap persiapan terdiri dari (1) melaksanakan studi pendahuluan; (2) menyusun instrumen penelitian berupa kisi-kisi soal multirepresentasi, soal tes uraian, dan rubrik penskoran; (3) melaksanakan uji validasi instrumen penelitian oleh validator ahli; (4) melakukan perbaikan instrumen penelitian berdasarkan uji validasi oleh validator ahli; (5) melaksanakan uji coba soal yang telah dinyatakan valid; dan (6) menghitung nilai reliabilitas, validitas, tingkat kesukaran, dan daya pembeda butir soal.

Selanjutnya yaitu tahap pelaksanaan. Tahap pelaksanaan terdiri dari (1) melakukan tes tulis kepada siswa XI IPA 7 SMA Negeri 1 Krian yang dilakukan secara online melalui google classroom dan google meet; (2) mengoreksi jawaban tes multirepresentasi siswa; (3) melakukan wawancara yang dilakukan secara online melalui google meet; dan (4) menganalisis kemampuan multirepresentasi siswa.

\section{Teknik Analisis Data}

Data yang telah diperoleh selanjutnya dianalisis dengan cara mengoreksi dan memberikan skor pada jawaban siswa sesuai dengan pedoman penskoran, lalu menghitung persentase kemampuan multirepresentasi siswa pada setiap representasi dengan rumus:
$\%$ kemampuan $=\frac{\text { jumlah skor siswa }}{\text { skor maksimum }} \times 100 \%$

Selanjutnya menghitung rata-rata jumlah skor siswa pada soal materi kesetimbangan kimia pada masing-masing tingkat representasi makroskopik, representasi submikroskopik, dan representasi simbolik, lalu mengidentifikasi kategori kemampuan tiap representasi yang diperoleh dari perhitungan skor siswa sesuai skala kategori kemampuan yang dikemukakan oleh Arikunto (2012).

Tabel 1 Kategori Kemampuan

\begin{tabular}{|l|l|}
\hline \multicolumn{1}{|c|}{ Nilai } & \multicolumn{1}{c|}{$\begin{array}{c}\text { Kategori } \\
\text { kemampuan }\end{array}$} \\
\hline $81-100$ & Sangat Baik \\
\hline $61-80$ & Baik \\
\hline $41-60$ & Cukup \\
\hline $21-40$ & Kurang \\
\hline$<20$ & Sangat Kurang \\
\hline
\end{tabular}

Arikunto (2012).

Tahap selanjutnya yaitu menganalisis transkrip wawancara untuk memperjelas hal-hal yang tidak diperoleh dari pengamatan dan membuat kesimpulan mengenai multirepresentasi siswa pada tiap kemampuan representasi.

\section{HASIL DAN PEMBAHASAN}

Proses pembelajaran di masa pandemi Covid-19 dilakukan dengan sistem pembelajaran jarak jauh. Sehingga, guru dan siswa tidak bertemu secara langsung di sekolah, tetapi melalui media teknologi dan bantuan internet. Pembelajaran yang dilakukan di SMA Negeri 1 Krian ini juga dilakukan dengan sistem pembelajaran jarak jauh. Persentase kemampuan multirepresentasi siswa pada materi kesetimbangan kimia di masa pandemi covid-19 bardasarkan data yang diperoleh digambarkan pada tabel berikut:

Tabel 2 Persentase Hasil Kemampuan Multirepresentasi Siswa Berdasarkan Kategori Kemampuan (Arikunto, 2012).

\begin{tabular}{lll}
\hline $\begin{array}{l}\text { Kemampuan } \\
\text { representasi }\end{array}$ & $\begin{array}{l}\text { Persentase } \\
(\%)\end{array}$ & $\begin{array}{c}\text { Kategori } \\
\text { kemampuan }\end{array}$ \\
\hline Makroskopik & 35.01 & Kurang \\
\hline Submikroskopik & 40.59 & Kurang \\
\hline Simbolik & 50.55 & Cukup \\
\hline
\end{tabular}

Tabel 2 menggambarkan bahwa persentase kemampuan multirepresentasi siswa pada materi kesetimbangan kimia terbilang kurang pada level representasi makroskopik dan submikroskopik. 


\title{
Chemistry Education Practice, 4 (1), 2021 - 34
}

\author{
Zahro', Ismono
}

Hal ini dipengaruhi oleh cara penyampaian materi oleh guru yang terbatas pada masa pandemi Covid-19. Penyampaian materi hanya dilakukan dengan pembelajaran jarak jauh sehingga penjelasan kurang bisa dipahami siswa karena hanya terbatas pada video conference yang juga dapat dipengaruhi oleh sinyal sehingga terkadang saat pembelajaran telah dimulai, siswa terkendala oleh sinyal yang menyebabkan pembelajaran terpotong. Hal ini serupa dengan penelitian Asmuni (2020) yang mengungkapkan bahwa sejumlah siswa tinggal di wilayah yang kesulitan akses internet.

Hasil kemampuan representasi makroskopis yang didapat dalam penelitian ini tergolong rendah jika dibandingkan dengan penelitian terdahulu sebelum masa pandemi Covid-19 yang dilakukan oleh Wahyudi, Qurbaniah, dan Sartika (2018) dengan persentase sebesar 76,52\% (kategori baik). Pada pembelajaran jarak jauh, guru menggunakan metode ceramah yang membuat siswa kurang aktif dalam pembelajaran. Guru terbiasa melatihkan kemampuan representasi makroskopik dengan cara praktek di laboratorium pada saat pembelajaran tatap muka secara langsung, tetapi hal tersebut tidak dapat dilakukan di masa pandemi Covid-19, hal ini menjadi salah satu dampak pada kemampuan representasi makroskopik siswa yang rendah. Temuan ini serupa dengan review penelitian yang dilakukan oleh Farida et al. (2020) yang mengungkapkan bahwa banyak materi yang tidak dijelaskan secara detail dan juga kurang interaktif saat pembelajaran online.

Represetasi submikroskopik adalah level dimana siswa menggunakan pengetahuan dari pengalaman belajarnya untuk memahami konsep kimia yang bersifat abstrak. Submikroskopik didefinisikan sebagai tingkat representasi dimana perilaku zat ditafsirkan dalam hal yang tak terlihat dan molekuler. Kemampuan submikroskopik siswa ini dipengaruhi oleh pemahaman siswa pada representasi makroskopik. Sehingga, rendahnya kemampuan representasi submikroskopik siswa juga diakibatkan oleh dampak pandemi Covid-19 yang mengubah kegiatan belajar mengajar secara tiba-tiba menjadi daring. Hal ini sesuai dengan pendapat (Dewi, 2020) yang mengungkapkan bahwa perubahan ke pembelajaran online secara tidak langsung berpengaruh pada daya serap peserta didik. Temuan ini juga didukung oleh penelitian yang dilakukan oleh Abidin (2020) bahwa materi dari sekolah lebih mudah untuk dipahami oleh siswa dibandingkan dengan pembelajaran jarak jauh atau daring.

Guru telah terbiasa melatihkan representasi simbolik siswa dengan cara memberi soal-soal yang berbasis representasi simbolik, sehingga pada penelitian ini didapatkan persentase simbolik siswa lebih tinggi dibandingkan dengan kemampuan makroskopik dan submikroskopik siswa. Tetapi, persentase kemampuan representasi simbolik siswa ini masih tergolong dalam kategori cukup $(50,55 \%)$, hal ini masih terbilang rendah jika dibandingkan dengan penelitian yang dilakukan oleh Wahyudi, dkk (2018) yang memperoleh persentase sebesar $70,57 \%$ dengan kategori baik. Dalam hal ini terdapat perbedaan yang cukup signifikan yang diakibatkan oleh sistem pembelajaran jarak jauh atau daring yang dirasa kurang efektif jika dibandingkan dengan pembelajaran yang dilakukan tatap muka secara langsung. Temuan ini juga didukung oleh pendapat (Mastura \& Santaria, 2020) yang menyatakan bahwa ketidakmahiran guru dalam penggunaan teknologi mempengaruhi kualitas pembelajaran, sehingga guru harus merancang metode yang sesuai dan tepat dalam proses pembelajaran daring.

Kemampuan representasi makroskopik siswa pada materi kesetimbangan kimia disajikan dalam tabel 3 sebagai berikut:

Tabel 3 Persentase Hasil Kemampuan Representasi Makroskopik Siswa Berdasarkan Kategori Kemampuan (Arikunto, 2012).

\begin{tabular}{cll}
\hline No Soal & $\begin{array}{l}\text { \% Representasi } \\
\text { Makroskopik }\end{array}$ & Kategori \\
\hline $\mathbf{1}$ & 54.84 & Cukup \\
\hline $\mathbf{2}$ & 26.88 & Kurang \\
\hline $\mathbf{3}$ & 51.61 & Cukup \\
\hline $\mathbf{4}$ & 23.66 & Kurang \\
\hline $\mathbf{5}$ & 18.06 & Sangat Kurang \\
\hline Rata-rata & $\mathbf{3 5 . 0 1}$ & Kurang
\end{tabular}

Berdasarkan tabel 3, rata-rata kemampuan representasi makroskopik siswa terbilang kurang dengan nilai rata-rata persentase sebesar $35.01 \%$. Butir soal nomor 1 dan 3 mendapat kategori cukup dengan nilai persentase berturut-turut sebesar $54.84 \%$ dan $51.61 \%$. Butir soal nomor 2 dan 4 tergolong dalam kategori kurang dengan nilai persentase berturut-turut sebesar $26.88 \%$ dan $23.66 \%$. Sedangkan pada butir soal nomor 5 mendapat kategori sangat kurang dengan nilai persentase sebesar $18.06 \%$. 


\section{Chemistry Education Practice, 4 (1), 2021 - 35}

Zahro', Ismono

Butir soal nomor 1 mendapat kategori cukup dan merupakan nilai tertinggi jika dibandingkan dengan soal representasi makroskopik yang lain. Siswa diminta untuk menjelaskan pengertian kesetimbangan dinamis berdasarkan fenomena yang diberikan yaitu air di dalam botol tertutup pada butir soal nomor 1 . Sebanyak 4 siswa telah menjawab dengan lengkap dan benar, tetapi sebanyak 27 siswa masih belum mampu menjelaskan secara lengkap mengenai nilai laju reaksi yang sama antara reaktan dan produk pada sistem kesetimbangan kimia.

Kemampuan representasi makroskopik siswa pada butir soal nomor 2, siswa diminta untuk memprediksi arah pergeseran kesetimbangan kimia berdasarkan fenomena yang diberikan yaitu $\mathrm{CuSO}_{4}$ berwarna biru yang direaksikan dengan $\mathrm{NaCl}$ menghasilkan $\mathrm{CuCl}_{2}$ berwarna hijau pada suhu $60-70^{\circ} \mathrm{C}$ dan kembali menjadi warna biru pada suhu $10-15^{\circ} \mathrm{C}$. Sebanyak 10 siswa mendapat skor 0 , sebanyak 17 siswa mendapat skor 5 , dan 4 siswa mendapat skor 10 , sedangkan skor maksimum dari soal ini adalah 15. Kesalahan jawaban dari kebanyakan siswa yaitu tidak dapat menjelaskan secara terperinci mengenai warna yang terbentuk yang disebabkan oleh suhu yang diberikan. Siswa hanya mampu menyebutkan kesetimbangan bergeser ke arah endoterm atau eksoterm tanpa mengaitkan dengan perubahan warna yang terjadi.

Selanjutnya, butir soal nomor 3 memiliki nilai kemampuan representasi sebesar $51.61 \%$ yang masuk dalam kategori cukup. Siswa diminta untuk mengungkapkan bagaimana intensitas warna coklat pada reaksi penguraian gas $\mathrm{N}_{2} \mathrm{O}_{4}$ yang terbentuk apabila konsentrasi $\mathrm{N}_{2} \mathrm{O}_{4}$ ditambah. Sebanyak 8 siswa menjawab salah dengan menyebutkan bahwa intensitas warna coklat berubah menjadi coklat muda. Hal ini menunjukkan bahwa terdapat kesalahan konsep yang dipahami oleh siswa dimana seharusnya jawaban yang benar adalah intensitas warna coklat semakin pekat karena adanya pergeseran kesetimbangan ke arah $\mathrm{NO}_{2}$.

Butir soal nomor 4 memiliki nilai persentase yang kurang. Siswa diminta untuk memprediksikan arah pergeseran kesetimbangan kimia dengan disertai penjelasan berdasarkan fenomena yang diberikan yaitu perubahan warna pada penguraian $[\mathrm{FeSCN}]^{2+}$ saat konsentrasi $\mathrm{Fe}^{3+}$ ditambah. Warna merah yang makin pekat menandakan bahwa kesetimbangan bergeser ke arah $[\mathrm{FeSCN}]^{2+}$ karena adanya penambahan konsentrasi dari ion besi (III) sehingga sistem dari ion besi (III) akan bekerja untuk mengurangi konsentrasinya dengan menggeser ke arah reaktan untuk mencapai kesetimbangan. Pada soal ini, jawaban siswa tidak ada yang menjawab dengan benar dan lengkap. Siswa hanya menyebutkan mengenai arah pergeseran kesetimbangan tanpa memberikan penjelasan terkait $\mathrm{Fe}^{3+}$ yang akan bekerja untuk mengurangi konsentrasinya dengan menggeser ke arah reaktan untuk mencapai kesetimbangan.

Kemampuan representasi makroskopik terendah terletak pada butir soal nomor 5 tergolong sangat kurang. Pada soal ini siswa diberikan suatu alur percobaan yang menunjukkan berbagai perubahan warna yang terjadi apabila diberikan penambahan larutan KSCN dengan konsentrasi yang berbeda, siswa diminta menganalisis mengapa dapat dihasilkan warna yang berbeda. Penambahan larutan KSCN $1 \mathrm{M}$ akan menambah konsentrasi ion $\mathrm{SCN}^{-}$, sehingga kesetimbangan akan bergeser ke arah kanan atau produk sehingga warna larutan menjadi merah bata. Penambahan larutan KSCN 0,001 akan mengurangi konsentrasi reaktan sehingga kesetimbangan akan bergeser ke arah kiri atau reaktan dan warna larutan semakin pudar. Dari 31 siswa, hanya 2 siswa yang dapat menjawab dengan benar dan lengkap. Jawaban siswa yang tidak lengkap hanya menyebutkan bahwa pergeseran terjadi karena terdapat perbedaan konsentrasi tanpa menjelaskan dan mengaitkan dengan alur percobaan yang diberikan.

Berdasarkan wawancara yang dilakukan, siswa kesulitan untuk memahami secara makroskopik karena siswa tidak melakukan praktikum secara langsung akibat adanya covid19 yang memaksa untuk melakukan pembelajaran jarak jauh. Kemampuan representasi makroskopik biasa dilatihkan dengan cara melakukan aktivitas pengamatan di alam sekitar atau melalui praktikum yang dilakukan di laboratorium (Farida et al. 2018). Tetapi dengan adanya pandemi Covid-19 yang memaksa keadaan untuk melakukan pembelajaran secara daring, kegiatan praktikum di laboratorium yang biasa dilakukan di sekolah ini ikut terkena dampaknya. Sehingga siswa tidak dapat melakukannya secara langsung. Selain itu, guru juga tidak memberikan suatu video atau media pengganti praktikum yang dapat dilakukan secara daring. Hal-hal tersebut mempengaruhi kemampuan representasi makroskopik siswa sehingga kemampuan yang dimiliki siswa di masa pandemi covid-19 tergolong rendah. 


\title{
Chemistry Education Practice, 4 (1), 2021 - 36
}

\author{
Zahro', Ismono
}

Kemampuan representasi submikroskopik siswa pada materi kesetimbangan kimia pada materi kesetimbangan kimia disajikan dalam tabel 4 sebagai berikut:

Tabel 4 Persentase Hasil Kemampuan

Representasi Submikroskopik Siswa

Berdasarkan Kategori Kemampuan (Arikunto, 2012).

\begin{tabular}{cll}
\hline No Soal & $\begin{array}{l}\text { \% } \\
\text { Submikroskopik }\end{array}$ & Representasi \\
\hline $\mathbf{6}$ & 56.99 & Cukup \\
\hline $\mathbf{7}$ & 43.55 & Cukup \\
\hline $\mathbf{8}$ & 57.26 & Cukup \\
\hline $\mathbf{9}$ & 32.26 & Kurang \\
\hline $\mathbf{1 0}$ & 12.90 & Sangat Kurang \\
\hline Rata-rata & $\mathbf{4 0 . 5 9}$ & Kurang \\
\hline
\end{tabular}

Berdasarkan tabel 4, rata-rata kemampuan representasi submikroskopik siswa terbilang kurang dengan nilai rata-rata persentase sebesar 40.59\%. Pada butir soal nomor 6, 7, dan 8 tergolong dalam kategori cukup dengan nilai persentase berturut-turut sebesar $56.99 \%$, $43.55 \%$, dan $57.26 \%$. Selanjutnya, pada butir soal nomor 9 mendapat kategori kurang dengan nilai persentase sebesar $32.26 \%$. Sedangkan pada butir soal nomor 10 termasuk dalam kategori sangat kurang dengan nilai persentase sebesar $12.90 \%$.

Pada butir soal nomor 6, siswa diminta untuk menjelaskan mengapa katalis tidak mempengaruhi arah pergeseran kesetimbangan kimia. Katalis tidak mempengaruhi arah pergeseran kesetimbangan kimia karena katalis hanya mampu mempercepat laju reaksi agar kesetimbangan lebih cepat tercapai, tetapi tidak dapat membuat reaksi. Keberadaan katalis dengan demikian tidak mengubah tetapan kesetimbangan dan tidak menyebabkan pergeseran kesetimbangan. Dari seluruh jawaban siswa, sebanyak 22 siswa dapat menyebutkan bahwa katalis berfungsi untuk mempercepat laju reaksi, tetapi tidak dapat menyebutkan bahwa katalis tidak dapat membuat reaksi baru yang akan menyebabkan pergeseran kesetimbangan kimia.

Sedangkan pada butir soal nomor 7 , siswa diminta untuk menjelaskan proses terjadinya pergeseran kesetimbangan yang disebabkan oleh suhu. Suhu yang dinaikkan sama artinya dengan meningkatkan kalor atau menambah energi ke dalam sistem, sehingga kondisi ini akan memaksa kalor yang diterima sistem untuk dipergunakan, oleh sebab itu reaksi semakin bergerak menuju arah reaksi endoterm. Begitu juga sebaliknya. Sebaliknya, menurunkan suhu pada reaksi akan menyebabkan kesetimbangan bergeser ke reaksi yang bersifat eksotermis. Dari seluruh jawaban siswa hanya ada 1 siswa yang dapat menjawab dengan lengkap dan benar. Kesalahan dari jawaban siswa diperoleh bahwa siswa tidak dapat menjelaskan mengenai suhu yang ditambahkan akan memaksa sistem untuk mempergunakannya sehingga memengaruhi pergeseran kesetimbangan kimia.

Selanjutnya, siswa diminta untuk menjelaskan tentang proses terjadinya pergeseran kesetimbangan yang disebabkan oleh perubahan konsentrasi pada butir soal nomor 8. Reaksi sistem akan mengurangi konsentrasi zat tersebut jika konsentrasi salah satu zat pada saat ditambahkan, sehingga kesetimbangan akan bergeser ke arah yang berlawanan dari konsentrasi zat yang ditambahkan. Sebaliknya, pada saat konsentrasi salah satu zat diperkecil maka kesetimbangan akan bergeser ke arah zat yang konsentrasinya diperkecil karena reaksi sistem akan menambah zat yang dikurangi. Kesalahan jawaban pada 20 siswa di soal ini adalah siswa hanya menyebutkan arah pergeseran apabila salah satu sistem ditambahkan konsentrasinya. Siswa tidak menjelaskan proses yang terjadi di dalamnya dimana saat konsentrasi salah satu zat diperkecil maka reaksi sistem akan menambah zat yang dikurangi sehingga kesetimbangan akan bergeser ke arah zat yang konsentrasinya diperkecil.

Kemampuan representasi pada butir soal nomor 9 tergolong kurang. Pada butir soal ini siswa diminta untuk menjelaskan proses terjadinya pergeseran arah kesetimbangan kimia yang disebabkan oleh pengaruh perubahan tekanan dan volume. Dari analisis jawaban seluruh siswa, sebanyak 24 siswa belum mampu untuk memberikan penjelasan mengenai hubungan antara perubahan tekanan dengan volume. Siswa hanya menyebutkan apabila volume diperkecil maka kesetimbangan akan bergeser ke arah jumlah koefisien reaksi kecil dan begitu sebaliknya. Dan juga tidak banyak siswa yang menyebutkan bahwa kesetimbangan tidak akan berubah apabila reaksi tersebut tidak memiliki selisih jumlah mol gas.

Butir soal nomor 10 memiliki nilai persentase terendah yaitu $12.90 \%$ dengan kategori sangat kurang. Siswa diminta untuk menjelaskan proses tercapainya kesetimbangan berdasarkan grafik yang diberikan. Hanya ada 3 siswa yang dapat menjawab dengan lengkap dan 
benar. Kesalahan siswa dalam menjawab soal ini yaitu siswa tidak menjelaskan mengenai kesetimbangan, namun mengenai proses terjadinya laju reaksi. Pemahaman konsep siswa yang tidak dimiliki secara utuh salah satunya disebabkan oleh kurangnya kecakapan siswa untuk menangkap maksud penjelasan dari bentuk simbolik dalam model diagram submikroskopik dan juga sebaliknya. Siswa tidak dapat mengartikan suatu bentuk representasi kedalam bentuk yang lainnya tanpa pemahaman yang tepat dari konsep yang mendasarinya.

Dalam melatihkan memahami representasi makroskopik dahulu. Sedangkan, berdasarkan hasil penelitian yang telah dilakukan, hasil kemampuan representasi makroskopik siswa tergolong rendah. Hal ini sangat berpengaruh pada kemampuan representasi submikroskopik siswa. Berdasarkan hasil wawancara siswa, siswa tidak memahami proses yang terjadi secara submikroskopis karena siswa merasa sulit memahami pembelajaran yang hanya berisi penjelasan tanpa adanya visualisasi. Selain itu, pembelajaran yang dilakukan secara daring di masa pandemi Covid-19 mengakibatkan kurangnya komunikasi antara guru dan siswa, sehingga pada saat siswa merasa kesulitan untuk memahami materi, siswa tidak dapat menyampaikannya karena terkendala waktu yang lebih singkat dibandingkan dengan pembelajaran yang dilakukan secara tatap muka di sekolah. Hal ini serupa dengan review dari penelitian yang dilakukan oleh Farida (2020) yang menyampaikan bahwa representasi submikroskopik sukar dipahami apabila hanya disampaikan dengan penjelasan tanpa adanya visualisasi dengan penjelasan interaktif dua arah. Dengan bantuan visualisasi menggunakan video, animasi, dan juga augmented reality dapat membantu untuk merepresentasikan fenomena submikroskopis (Wulandari dkk, 2019).

Kemampuan representasi simbolik siswa pada materi kesetimbangan kimia pada materi kesetimbangan kimia disajikan dalam tabel 5 sebagai berikut:

Tabel 5 Persentase Hasil Kemampuan Representasi Simbolik Siswa Berdasarkan

Kategori Kemampuan (Arikunto, 2012).

No Soal \% Representasi Kategori Simbolik

$11 \quad 68.55 \quad$ Baik

\begin{tabular}{cll}
\hline $\mathbf{1 2}$ & 65.16 & Baik \\
\hline $\mathbf{1 3}$ & 72.26 & Baik \\
\hline $\mathbf{1 4}$ & 46.77 & Cukup \\
\hline $\mathbf{1 5}$ & 0.00 & $\begin{array}{l}\text { Sangat } \\
\text { Kurang }\end{array}$ \\
\hline Rata-rata & $\mathbf{5 0 . 5 5}$ & Cukup \\
\hline
\end{tabular}

Berdasarkan tabel 5, rata-rata kemampuan representasi simbolik siswa terbilang cukup dengan nilai rata-rata persentase sebesar $50.71 \%$. Kemampuan siswa dalam menjawab butir soal nomor 11,12 , dan 13 tergolong dalam kategori baik dengan nilai persentase berturut-turut sebesar $68.55 \%, 65.16 \%$, dan $72.26 \%$. Butir soal nomor 14 memiliki nilai persentase sebesar $46.77 \%$ sehingga tergolong dalam kategori cukup. Sedangkan pada butir soal nomor 15 mendapat nilai $0.81 \%$ yang tergolong dalam kategori sangat kurang karena seluruh siswa tidak dapat menjawab soal tersebut dengan benar.

Nilai kemampuan representasi simbolik siswa diukur melalui butir soal nomor 11, 12, 13, 14, dan 15. Butir soal nomor 11 memiliki nilai persentase $68.55 \%$ dengan kategori baik. Pada butir soal nomor 11, siswa diminta untuk menentukan derajat disosiasi berdasarkan konsentrasi yang diketahui. Seluruh siswa telah menjawab dengan benar tetapi 11 diantaranya tidak menuliskan perhitungan secara lengkap sehingga tidak menggambarkan pemahaman konsep yang utuh. Pada soal nomor 12, siswa diminta untuk menentukan tetapan kesetimbangan berdasarkan reaksi yang dituliskan pada soal. Kesalahan siswa pada soal ini terdapat pada proses perhitungan yang tidak sesuai karena ketidak telitian dan juga rumus yang digunakan tidak sesuai. Kemampuan representasi tertinggi terletak pada butir soal nomor 13 dengan kategori baik. Siswa diminta untuk menentukan nilai $\mathrm{Kc}$ berdasarkan konsentrasi kesetimbangan. Kesalahan siswa pada butir soal ini terletak pada rumus yang digunakan dimana seharusnya konsentrasi $\mathrm{H}_{2}$ dikuadratkan terlebih dahulu.

Selanjutnya, butir soal nomor 14 mendapat kategori cukup. Siswa diminta untuk menghitung harga Kp reaksi berdasarkan Kc yang telah diketahui. Kesalahan siswa pada butir soal ini yaitu tidak menuliskan perhitungan dengan benar dimana seharusnya $\Delta \mathrm{n}$ dituliskan sebagai pangkat, siswa salah menuliskannya sebagai perkalian. Lalu, pada butir soal nomor 15 siswa diminta untuk menentukan nilai tekanan parsial gas hasil reaksi berdasarkan $\mathrm{Kp}$ dan tekanan 


\title{
Chemistry Education Practice, 4 (1), 2021 - 38
}

\author{
Zahro', Ismono
}

parsial gas pereaksi. Tidak ada siswa yang dapat menjawab dengan benar pada butir soal ini. Seluruh siswa salah dalam memilih rumus yang digunakan.

Berdasarkan hasil analisis soal nomor 11, $12,13,14$, dan 15 diperoleh bahwa kategori kemampuan representasi simbolik siswa dari hasil penelitian ini tergolong cukup. Siswa lebih mudah memahami soal-soal dengan representasi simbolik jika dibandingkan dengan kemampuan makroskopik dan submikroskopik, namun beberapa siswa masih kebingungan dalam menentukan rumus yang akan digunakan dalam perhitungan. Tetapi, pada kemampuan makroskopik dan submikroskopik yang tergolong rendah menunjukkan bahwa pemahaman representasi simbolik siswa tidak dihubungkan dengan kemampuan makroskopik dan submikroskopiknya. Siswa hanya mengandalkan hafalan tanpa memahami konsep. Hal ini didukung oleh pendapat Treagust, David (2018) yang menyatakan bahwa representasi simbolik merupakan penggambaran yang mewakili perubahan zat pada level makroskopik dan submikroskopik. Berdasarkan wawancara guru, kemampuan simbolik siswa di pembelajaran tatap muka secara langsung tergolong baik. Tetapi pada saat masa pandemi covid-19, kemampuan siswa menurun. Hal ini disebabkan oleh metode pembelajaran daring yang kurang efektif dibandingkan dengan pembelajaran tatap muka secara langsung. Hal ini serupa dengan temuan Farida et al. (2020) yang menjelaskan bahwa materi pembelajaran yang mengandung konten perhitungan, persamaan reaksi, dan mekanisme reaksi akan lebih mudah dipahami apabila dijelaskan secara langsung dengan pengawasan secara langsung.

Kemampuan menjawab soal berbasis simbolik yang rendah ini perlu dilakukan perbaikan pada siswa dan juga perbaikan pada cara penyampaian guru dalam proses belajar mengajar di masa pandemi covid-19. Kemampuan siswa dapat ditingkatkan dengan cara berlatih mengerjakan soal dengan memahami konsep dari soal tersebut. Sedangkan perbaikan yang dapat dilakukan oleh guru adalah dengan menerapkan metode pembelajaran dengan menggunakan tiga level pembelajaran kimia yang dapat diterapkan pada masa pandemi covid-19 (Sulistyowati dan Poedjiastoeti 2013).

\section{SIMPULAN}

Berdasarkan analisis data hasil penelitian dan pembahasan dari hasil tes multirepresentasi pada materi kesetimbangan kimia terhadap siswa kelas XI IPA 7 SMA Negeri 1 Krian dapat disimpulkan bahwa kemampuan representasi siswa pada level representasi makroskopik diperoleh persentase rata-rata sebesar $35.01 \%$ yang termasuk dalam kategori kurang., kemampuan representasi siswa pada level representasi submikroskopik diperoleh persentase rata-rata sebesar $40.59 \%$ yang termasuk dalam kategori kurang, dan kemampuan representasi siswa pada level representasi submikroskopik diperoleh persentase rata-rata sebesar $50.71 \%$ yang termasuk dalam kategori cukup.

Sehingga disarankan untuk menggunakan berbagai media atau bahan ajar yang dapat mengintegrasikan tiga level representasi siswa secara proporsional dan hasil dari penelitian dapat digunakan untuk menunjang peneliti lain yang akan mengembangkan strategi pembelajaran pada materi kesetimbangan kimia sehingga dapat meningkatkan kemampuan multirepresentasi siswa di masa pandemi covid19.

\section{DAFTAR PUSTAKA}

Abidin, Zainal, Adeng Hudaya, dan Dinda Anjani. 2020. "Efektivitas Pembelajaran Jarak Jauh Pada Masa Pandemi Covid-19." Research and Development Journal Of Education.

Adadan, Emine. 2013. "Using Multiple Representations to Promote Grade 11 Students' Scientific Understanding of the Particle Theory of Matter." Research in Science Education. doi: 10.1007/s11165012-9299-9.

Arikunto, Suharsimi. 2012. Prosedur Penelitian: Suatu Pendekatan Praktik (Edisi Revisi).

Asmuni, Asmuni. 2020. "Problematika Pembelajaran Daring di Masa Pandemi Covid-19 dan Solusi Pemecahannya." Jurnal Paedagogy. doi: 10.33394/jp.v7i4.2941.

Chuenmanee, C., \& Thathong, K. 2018. The Current Practice of Using Multiple Representations in Year 4 Science Classroom. AIP Publishing LLC.

Creswell, John W., dan J. David Creswell. 2018. Research Design: Qualitative, Quantitative, and Mixed Methods Approach.

Davidowitz, Bette, Gail Chittleborough, dan Eileen Murray. 2010. "Student-generated submicro diagrams: A useful tool for teaching and learning chemical equations 
and stoichiometry." Chemistry Education Research and Practice. doi: $10.1039 / \mathrm{c} 005464 \mathrm{j}$.

Dewi, W. A. (2020). Dampak Covid-19 Terhadap Implementasi Pembelajaran Daring di Sekolah Dasar. Edukatif: Jurnal Ilmu Pendidikan, 2(1), 55-61.

Farida, I., I. Helsy, I. Fitriani, dan M. A. Ramdhani. 2018. "Learning Material of Chemistry in High School Using Multiple Representations." in IOP Conference Series: Materials Science and Engineering.

Farida, I., L. Liliasari, W. Sopandi, dan D. H. Widyantoro. 2017. "A web-based model to enhance competency in the interconnection of multiple levels of representation for preservice teachers." in Ideas for 21st Century Education.

Farida, Ida, Risa Rahmawati Sunarya, Riri Aisyah, dan Imelda Helsy. 2020. "Pembelajaran Kimia Sistem Daring di Masa Pandemi Covid-19 Bagi Generasi Z." KTI UIN Sunan Gunung Djati.

Irwansyah, F. S., I. Ramdani, dan I. Farida. 2017. "The development of an Augmented Reality (AR) technology-based learning media in metal structure concept." in Ideas for 21st Century Education.

Jonsson, B., Waling, M., Olafsdottir, A. S., Lagstrom, H., Wergedahl, H., Olsson, C., \& Hornell, A. 2017. "The Effect Of Schooling On Basic Cognition In Selected Nordic Countries." Europe's Journal of Psychology, 13(4), 645-666. Retrieved from https://doi.org/10.5964/ejop.v13i4.1339

Mastura, M., \& Santaria, R. (2020). Dampak Pandemi Covid-19 Terhadap Proses Pengajaran Bagi Guru Dan SIswa. Jurnal Studi Guru Dan Pembelajaran, 3(2), 289295.

Munir. 2012. Pembelajaran Jarak Jauh Berbasis Teknologi Informasi dan Komunikasi. Bandung: Alfabeta.

Safitri, Nanda Cahaya, Euis Nursaadah, dan Imas Eva Wijayanti. 2019. "Analisis Multipel Representasi Kimia Siswa pada Konsep Laju Reaksi." EduChemia (Jurnal Kimia dan Pendidikan). doi: 10.30870/educhemia.v4i1.5023.

Stojanovska, Marina, Vladimir M. Petruševski, dan Bojan Šoptrajanov. 2017. "Study Of The Use Of The Three Levels Of Thinking And Representation." Contributions, Section of Natural, Mathematical and Biotechnical Sciences. doi: 10.20903/csnmbs.masa.2014.35.1.52.

Sulistyowati, Tri, dan Sri Poedjiastoeti. 2013. "Kelayakan Multimedia Interaktif Berbasis Intertekstual Pada Materi Reaksi Kimia Untuk Kelas X Sma Feasibility of Interactive Multimedia Based on Intertextuality in Chemical Reaction Material for X-Grade Senior High School." Unesa Journal of Chemical Education 2(3):57-63.

Talanquer, V. 2011. "Macro, Submicro, and Symbolic: The Many Faces Of The Chemistry "Triplet"." International Journal Of Science Education, 33(2), 179-195. doi:10.1080/09500690903386435

Treagust, David, F. 2018. "The Importance of Multiple Representations for Teaching and Learning Science." Education Research Highlights in Mathematics, Science and Technology 2018 (December, 2018):21523.

Wulandari, I., Irwansyah, F. S., Farida, I., \& Ramdhani, M. A. 2019. "Development of student's submicroscopic representation ability on molecular geometry material using Augmented Reality (AR) media." Journal of Physics: Conference Series, 1280(3). https://doi.org/10.1088/17426596/1280/3/032016

Wahyudi, Widi, Mahwar Qurbaniah, dan Rody Putra Sartika. 2018. "Deskripsi Kemampuan Multirepresentasi Pada Materi Laju Reaksi Siswa Kelas Xi Ipa Sma Muhammadiyah 1 Ketapang." AR-RAZI Jurnal Ilmiah. doi: 10.29406/arz.v6i1.987. 